\title{
BENTUK PEMBELAJARAN BIDANG SAIN DALAM MENINGKATKAN MUTU DI PERGURUAN TINGGI
}

\author{
Oleh : Abhanda Amra*
}

\begin{abstract}
Science learning forms to improve the quality of university students' learning are aimed are aimed at figuring out learning models which promote students' learning ability simply and efficiently on the basis of knowledge and skills needed in learning process-self learning. Adapting current technology toward science learning has become one of the goals of learning model innovation. Furthermore, science leaning models have strength in 3 aspects: (1) problem-solving learning, (2) experience-based learning, and (3) individual and cooperation-based learning. Among some forms of learning can be applied in science learning are (a) learning model through analogy, (2) learning model through media, and (c) information technology (web)-based learning. Several components need to be well managed to ensure that such learning model innovation can be effectively applied to obtain the goals are: professional teachers, students, educational facilities, learnig process, curriculum, monitoring and evaluation.
\end{abstract}

Kata Kunci: pembelajaran, sain, mutu

\section{PENDAHULUAN}

I novasi pembelajaran banyak diperbincangkan dalam dunia pendidikan karena sangat diperlukan, terutama dalam menghasilkan model pembelajaran baru yang dapat memberikan hasil belajar lebih baik, peningkatkan efesiensi dan efektivitas pembelajaran menuju pembaharuan. Sering terjadi seorang dosen di Perguruan Tinggi kurang mempunyai bekal model pembelajaran karena hanya mementingkan penguasaan dan pendalaman materi kuliah serta pengalaman dalam bidang ilmunya, sehingga penyampaian materi kuliah tidak optimum.

Pengalaman pendidikan yang sering dihadapi di Perguruan Tinggi adalah bahwa banyak mahasiswa menganggap mata kuliah bidang sain sulit dipelajari, sehingga mahasiswa sudah terlebih dahulu merasa kurang mampu untuk mempelajarinya (Sakkashiri, 1991). Hal ini mungkin disebabkan oleh penyajian dosen terhadap materi kuliah yang kurang menarik, membosankan, sulit dan menakutkan sehingga mahasiswa kurang menguasai konsep dasar perkuliahan yang diikutinya, dan akhirnya perkuliahan terserbut menjadi tidak menarik lagi bagi kebanyakan mahasiswa.

Beberapa faktor penyebab kurangnya penguasaan materi perkuliahan bagi mahasiswa diantaranya adalah (1) sistematika dan urutan materi kuliah yang belum mampu memotivasi mahasiswa belajar karena langsung mengajarkan materi kuliah yang tergolong sulit tanpa memberikan pengertian dasar yang diperlukan (mata kuliah prasyarat), (2)

* Penulis adalah Lektor dalam Mata Kuliah Manajemen Pendidikan pada STAIN Batusangkar 
mahasiswa sering belajar dengan cara menghafal tanpa membentuk pengertian terhadap materi kuliah yang dipelajari, (3) materi kuliah yang diajarkan mengambang sehingga mahasiswa tidak dapat menemukan 'kunci' untuk mengerti materi perkuliahan yang sedang dipelajari, dan (4) dosen tertentu kurang berhasil menyampaikan 'konsep' bagi mahasiswa untuk menguasai materi yang diajarkan karena kurangnya penguasaan model pembelajaran (Lynch dan Waters, 1980).

Sebagai dosen dan orang yang menekuni bidang pendidikan maka kita harus selalu waspada terhadap materi kuliah yang sedang dan akan diajarkan kepada mahasiswa. dengan demikian, selain menyampaikan materi kuliah, seorang dosen harus terbeban untuk mengembangkan topik kuliah agar memberikan hasil belajar yang optimum (Boyce, dkk, 1997). Untuk mengembangkan penguasaan konsep pelajaran yang baik dibutuhkan komitmen mahasiswa dalam memilih belajar menjadi sesuatu yang 'berarti', yaitu dengan cara meningkatkan kemauan mahasiswa mencari hubungan konseptual antara pengetahuan yang dimiliki dengan yang dipelajari di dalam perkuliahan. Untuk mencapai tujuan ini maka diperlukan inovasi model pembelajaran yang dapat dipergunakan untuk meningkatkan kemampuan mahasiswa belajar dengan mudah dan efesien berdasarkan pengetahuan dan kemampuan yang dibutuhkan dalam proses pembelajaran, sehingga terjadi pergeseran pembelajaran dari perkuliahan formal menuju pembelajaran mandiri.

Inovasi dalam pendidikan sering dihubungkan dengan pembaharuan yang berasal dari hasil pemikiran kreatif, temuan dan modifikasi yang memuat ide dan metode yang dipergunakan untuk mengatasi suatu permasalahan pendidikan. Sedangkan model pembelajaran adalah suatu rencana atau pola yang dapat dipergunakan untuk membangun kurikulum, mendisain bahan instruksional dan sebagai pengarah terhadap kegiatan pembelajaran di dalam kelas atau di luar kelas (Joice dan Weil, 1980). Model pembelajaran harus dapat berfungsi sebagai alat komunikasi dalam penyampaian materi kuliah. Agar inovasi model pembelajaran berhasil optimum sesuai dengan tujuan yang diinginkan maka beberapa hal perlu dipertimbangkan dalam inovasi seperti seperti rasional teoritis, landasan pemikiran pembelajaran dan lingkungan belajar. Model pembelajaran dapat diakui apabila dapat dipergunakan secara luas dalam pembelajaran dan terbukti efektif dalam meningkatkan hasil belajar (prestasi belajar mahasiswa). dengan demikian, model pembelajaran sebaiknya fleksibel dan bertanggungjawab terhadap hasil dan tujuan pembelajaran sehingga penyampaian materi menjadi terfokus.

\section{BENTUK PEMBELAJARAN SAIN}

Bentuk pembelajaran sain adalah suatu pendekatan pengajaran meliputi strategi, metode dan prinsip pengajaran yang dipergunakan dalam pembelajaran bidang sian. Model pembelajaran bidang sain memiliki kelebihan dalam tiga aspek, yaitu (1) pembelajaran pemecahan masalah, (2) pembelajaran berdasarkan pengalaman, dan (3) pembelajaran berbasis individu dan kerjasama. Pembelajaran pemecahan masalah dilakukan untuk menuntun mahasiswa melakukan penyelidikan melalui permasalahan bermakna yang diajukan oleh dosen dalam perkuliahan. Pembelajaran ini akan membawa mahasiswa pada situasi nyata sehingga dapat menuntun mahasiswa membangun pengetahuan dan keterampilan melalui pembelajaran mandiri.

Pembelajaran berdasarkan pengalaman yang dilakukan untuk menjelaskan pengalaman belajar yang di- 
miliki dosen kepada mahasiswa. Pembelajaran ini dapat disampaikan melalui demonstrasi terhadap pengetahuan atau keterampilan yang dimiliki oleh dosen sehingga mahasiswa memperoleh pengetahuan dan keterampilan standar dalam melakukan kegiatan akademik, misalnya dalam percobaan atau praktikum. Pembelajaran berbasis individu dan kerja sama dilakukan untuk membantu mahasiswa memahami konsepkonsep materi kuliah yang sulit, terutama bagi mahasiswa dengan tingkat kemampuan akademik berbeda. Model pembelajaran ini memberikan kesempatan kepada mahasiswa untuk menyelesaikan tugas yang diberikan oleh dosen secara mandiri maupun secara berkelompok dalam memecahkan permasalahan dalam kehidupan nyata melalui kegiatan kelas dan laboratorium. Model ini mampu membawa mahasiswa untuk dapat belajar aktif sehingga terjadi interaksi diantara mahasiswa (Giancarlo dan Slunt, 2004).

Inovasi model pembelajaran sain juga mengalami perkembangan sejalan dengan kemajuan dan perkembangan teknologi. Melalui inovasi maka model pembelajaran yang ada dikembangkan dan ditingkatkan untuk melahirkan model-model pembelajaran baru yang menarik. Dalam diskusi ini, beberapa inovasi model pembelaran yang dipergunakan dalam pembelajaran sain akan dibahas, diantaranya adalah (1) model pembelajaran menggunakan analogi, (2) model pembelajaran menggunakan media, (3) model pembelajaran berbasis teknologi informasi, (4) model pembelajaran menggunakan komputer, dan (5) model pembelajaran menggunakan web. Masing-masing model pembelajaran ini akan dijelaskan secara singkat berikut ini.

\section{Pembelajaran Menggunakan Analogi}

Model pembelajaran menggunakan analogi adalah pembelajaran yang menggunakan analogi dalam penjelasan fenomena ilmiah. Model pembelajaran menggunakan analogi sangat berperan dalam penjelasan ilmiah, pengamatan dan penemuan. Model pembelajaran ini dilakukan untuk menolong mahasiswa mengaplikasikan pengetahuan dan keadaan lingkungan nyata yang relevan pada saat mempelajari pengetahuan baru. Sebagai contoh, model pembelajaran dengan menggunakan analogi antara pergerakan planet dengan arah pergerakan jarum jam, pembelajaran menggunakan visualisasi analogi antara lemari buku dengan model atom Bohr, dan visualisasi analogi antara aliran air dengan aliran listrik (Glynn, ddk, 2001)

Banyak pembelajaran sain yang kompleks dapat dijelaskan menggunakan analogi, terutama untuk menjelaskan konsep-konsep ilmiah di dalam buku ajar. Akan tetapi, model pembelajaran menggunakan analogi sangat sulit dilakukan oleh dosen yang kurang berpengalaman. Kehati-hatian dan pertimbangan yang cukup matang harus dilakukan dalam menggunakan analogi yang kurang memadai akan membingungkan mahasiswa. Agar pembelajaran dapat efektif menggunakan analogi maka dosen dalam mendesain model pembelajaran analogi harus melakukan langkah-langkah sebagai berikut: (1) memperkenalkan konsep target sehingga topik yang akan dianalogikan jelas, (2) menunjukkan analogi yang sesuai dan mudah dipahami dengan menggunakan bahan, materi atau lingkungan nyata, (3) mengidentifikasi bagian yang relevan dari suatu target dengan analogi yang dipersiapkan, (4) menentukan kesesuaian antara konsep target dengan analogi yang ditunjukkan, (5) menyatakan bagian-bagian yang beranalogi, dan (6) membuat kesimpulan. 


\section{Pembelajaran Menggunakan Media}

Media pendidikan dapat dipergunakan untuk membangun pemahaman dan penguasaan objek pendidikan. Beberapa media pendidikan yang sering dipergunakan dalam pembelajaran diantaranya media cetak, elektronik, model dan peta (Kreyenhbuhl, 1991). Media cetak banyak dipergunakan untuk pembelajaran dalam menjelaskan materi kuliah yang kompleks sebagai pendukung buku ajar. Pembelajaran dengan menggunakan media cetak akan lebih efektif jika bahan ajar sudah dipersiapkan dengan baik yang dapat memberikan kemudahan dalam menjelaskan konsep yang diinginkan kepada mahasiswa.

Media elektronik seperti video dipergunakan di dalam pembelajaran sain. Penggunaan video sangat baik dipergunakan untuk membantu pembelajaran, terutama untuk memberikan penekanan pada materi kuliah yang sangat penting untuk diketahui oleh mahasiswa. Harus disadari bahwa video bukan diperuntukkan untuk menggantungkan pengajaran pada materi yang diperlihatkan pada video, sehingga pengaturan penggunaan waktu dalam menggunakan video sangat perlu, misalnya maksimum 20 menit. Inovasi model pembelajaran dengan menggunakan video dalam percobaan yang menuntut keterampilan seperti pada kegiatan praktikum sangat efektif bila dilakukan dengan penuh persiapan. Sebelum praktikum dimulai, video dipergunakan untuk membantu mahasiswa memberikan arahan terhadap apa yang harus mereka amati selama percobaan. Selanjutnya video diputar kembali pada akhir praktikum untuk mengklarifikasi hal-hal penting yang harus diketahui oleh mahasiswa dari percobaan yang sudah dilakukan.

Media lain yang dipergunakan dalam pembelajaran sain adalah petakonsep. Penggunaan media petakonsep di dalam pendidikan sudah dilakukan sejak tahun 1977, yaitu dalam pengajaran Biologi (Novak, 1977) dan sejak itu media petakonsep berkembang dan telah dipergunakan dalam pembelajaran sain. Media petakonsep bertujuan untuk membangun pengetahuan siswa dalam belajar secara sistematis, yaitu sebagai teknik untuk meningkatkan pengetahuan siswa dalam penguasaan konsep belajar dan pemecahan masalaha (Pandley, dkk. 1994). Petakonsep merupakan media pendidikan yang dapat menunjukkan konsep ilmu yang sistematis, yaitu dimulai dari inti permasalahan sampai pada bagian pendukung yang mempunyai hubungan satu dengan lainnya, sehingga dapat membentuk pengetahuan dan mempermudah pemahaman suatu topik pelajaran. Langkah yang dilakukan dalam inovasi model pembelajaran dengan media petakonsep adalah memikirkan apa yang menjadi 'pusat' topik yang akan diajarkan, yaitu sesuatu yang dianggap sebagai 'inti' dimana konsepkonsep pendukung lain dapat diorganisasikan terhadap konsep inti, kemudian menuliskan kata, peristilahan dan rumus yang memiliki arti, yaitu yang mempunyai hubungan dengan konsep inti, dan pada akhirnya membentuk satu peta hubungan integral dan saling terkait antara konsep atas-bawah-samping.

\section{Pembelajaran Berbasis Teknologi Informasi}

Adaptasi teknologi baru terhadap kebutuhan pembelajaran bidang sain menjadi salah satu sasaran inovasi model pembelajaran. Kemajuan dalam teknologi komunikasi dan informasi telah memudahkan manusia untuk dapat saling berhubungan dengan cepat, mudah dan terjangkau serta potensi untuk inovasi model pembelajaran. Penemuan berbagai jenis teknologi yang dapat digunakan menjadi fasilitas pendidikan seperti komputer, CD-ROOM dan Lan 
telah mendorong pemanfaatnya dalam inovasi model pembelajaran. Pendekatan penggunaan teknologi baru yang dipadukan dengan teori paedagogik telah melahirkan pembelajaran e-learning (Rosenberg, 2001). E-learning telah memberikan pengaruh sangat besar dalam inovasi model pembelajaran. $E$ learning identik dengan penggunaan teknologi internet untuk menyampaikan materi kuliah. Sensitifitas pembelajaran sain terhadap perubahan dan kemajuan yang sangat cepat mengharuskan untuk menggunakan teknologi informasi dalam komunikasi dan pembelajaran. Inovasi model pembelajaran berbasis teknologi informasi diawali dari penggunaan komputer dalam pembelajaran secara offline dan kemudian berkembang dengan penggunaan web dalam pembelajaran secara online.

\section{Pembelajaran Menggunakan Kom- puter}

Penggunaan komputer dalam pembelajaran sain sangat menguntungkan karena dapat memberikan kesempatan luas kepada mahasiswa dan dosen untuk mengembangkan kemampuannya dalam investigasi dan analisis, sekaligus dapat membentuk pengetahuan dan pemahaman yang baru dalam melihat suatu permasalahan, serta mendapatkan cara pemecahan masalah melalui pembelajaran. Pembelajaran menggunakan komputer sangat baik digunakan dalam pengumpulan, visualisasi dan analisis data sederhana dan kompleks. Dengan menggunakan komputer maka pengumpulan data dapat dilakukan sebanyak mungkin, visualisasi data dapat dilakukan bervariasi, dan pengolahan data dapat dilakukan sangat cepat setelah mendapatkan data pengamatan dari percobaan laboratorium. Banyak studi telah dilakukan yang menjelaskan pentingnya penggunaan komputer dalam pembelajaran sain (Lazarowictz dan Tamir, 1994).
Saat ini penggunaan komputer sebagai alat belar sangat menguntungkan karena telah tersedia berbagai jenis software dan hardware yang memudahkan untuk mengintegrasikan komputer dengan peralatan elektronik lain seperti video, kamera dan instrumen laboratorium. Penggunaan komputer dalam pembelajaran akan dapat meningkatkan efisiensi dan efektifitas pembelajaran, akan tetapi membutuhkan innovator yang terampil dan berpengalaman.

Pertimbangan utama yang dibutuhkan dalam penggunaan komputer dalam pembelajaran adalah ketersediaan dan kemauan dosen (innovator) untuk menggunakannya dalam inovasi model pembelajaran. Misalnya, seorang dosen telah melakukan inovasi pembelajaran untuk materi kuliah tertentu menggunakan PC di rumahnya, tetapi komputer yang tersedia di kampus tidak mampu mengoperasikan pembelajaran tersebut karena keterbatasan dalam software maupun hardware sehingga akan menghambat pengembangan inovasi itu sendiri. Ketidaksiapan mahasiswa dan dosen dalam mengaplikasikan model pembelajaran yang disebabkan oleh keterbatasan pengetahuan dalam pengoperasian komputer dalam pembelajaran juga dapat menjadi kendala dalam inovasi model pembelajaran.

\section{Pembelajaran Menggunakan WEB}

Penggunaan komputer sebagai alat bantu komunikasi dan pembelajaran telah dilakukan di Perguruan Tinggi dan menganggapnya sebagai satu kewajiban dan kebutuhan (Slocum, dkk. 2004). Perkembangan penggunaan komputer dalam pembelajaran telah mendorong pengaturan peralatan komputer sebagai alat bantu belajar yang disebut dengan computer managed learning (CML). CML didisain untuk membantu mahasiswa dalam jumlah besar dapat belajar secara mandiri dari sumber belajar yang sudah 
disediakan dalam komputer, LAN dan world wide wed (www). Model pembelajaran menggunakan CML menguntungkan karena kepada mahasiswa diberikan kebebasan untuk mendapatkan berbagai jenis sumber belajar yang tersedia sesuai dengan kebutuhan dan kemampuannya. Pembelajaran CML menyediakan berbagai jenis metodologi yang disesuaikan dengan materi kuliah yang akan diberikan kepada mahasiswa, sehingga mahasiswa dapat memilih cara termudah dan yang sesuai dengan kemampuannya. CML melalui web sangat efisien untuk penyampaian materi kuliah dan memberikan kesempatan kepada mahasiswa belajar dari mana saja dan kapan saja tanpa dibatasi tempat dan waktu belajar (Forsyt, dkk. 2004)

Pada saat ini inovasi model pembelajaran dengan menggunakan komputer berkembang sangat pesat terutama setelah tersedianya komputer 'superhighway' dan 'internet'. Melalui internet maka kendala keterjangkuan terhadap informasi antar perguruan tinggi dan sumber belajar dapat diatasi. Internet bukan hanya sebagai sarana informasi dan komunikasi, tetapi merupakan sumber belajar yang sangat penting karena materi pembelajaran saat ini banyak yang tersedia di dunia maya (web). Sumber belajar melalui internet ini sangat dibutuhkan oleh dosen di dalam meningkatkan kualitas pengajarannya. Prinsip utama model pembelajaran berbasis web adalah memberikan tanggung jawab besar terhadap mahasiswa. pembelajaran berbasis web memberikan kebebasan kepada mahasiswa dalam pengelolaan waktu belajar sehingga mahasiswa dapat mengoptimalkan pembelajarannya dengan cara menggunakan sumber belajar dalam waktu tidak terbatas. Menggunakan internet dalam pembelajaran sangat menguntungkan bagi mahasiswa dan dosen karena dapat mengakses informasi ilmiah secara lengkap dan jelas.

Inovasi pembelajaran berbasis web dalam pembelajaran sain banyak yang sudah berhasil seperti dijelaskan oleh Cann dan Dickneider (2004). Biasanya bahan ajar yang disediakan dalam pengajaran berbasis web terdiri atas modul yang dilengkapi dengan instruksi penggunaanya. Materi kuliah dapat juga disertai dengan presentasi Power Point yang dapat diakses oleh mahasiswa secara online. Pembelajaran berbasis web harus dilengkapi dengan berbagai jenis software yang dapat diakses dan di download oleh mahasiswa sehingga materi kuliah dan bahan yang diperlukan oleh mahasiswa dapat diakses sendiri oleh mahasiswa tanpa harus dituntun oleh dosen. Tersedianya fasilitas yang lengkap di dalam web akan memberi peluang bagi mahasiswa untuk mempelajari semua materi yang disediakan secara optimum. Model pembelajaran web ini juga menyediakan fasilitas "pertolongan" (help) bagi mahasiswa untuk membantu mahasiswa yang mengalami kesulitan dalam mengerti materi pembelajaran.

Model pembelajaran berbasis web juga harus menyediakan bahan evaluasi berupa bank soal dalam berbagai variasi, sederhana dan mudah untuk dikerjakan dan hasil penilaian cepat diperoleh. Pada umumnya evaluasi didisain dalam bentuk pilihan berganda, benar-salah, dan jawaban singkat dengan jumlah kata terbatas. Untuk membantu mahasiswa mengetahui apakah jawabannya benar atau salah maka hasil penilaian harus dapat diperoleh secara online. Fasilitasi remedial juga harus tersedia untuk menolong mahasiswa dalam meningkatkan pengetahuannya dan memperoleh jalan keluar apabila jawabannya tidak benar. Pembelajaran menggunakan internet memang sulit untuk diikuti di beberapa perguruan tinggi di Indonesia karena 
cepatnya perubahan yang terjadi dalam bidang penelitian dan pengembangan sering tidak diikuti oleh penyediaan dana dan fasilitas pendukung.

\section{KOMPONEN PEMBELAJARAN}

Beberapa komponen yang perlu dibenahi agar inovasi model pembelajaran dapat efekti untuk meningkatkan prestasi belajar mahasiswa adalah dosen profesional, mahasiswa, sarana dan prasarana pendidikan, proses pembelajaran, kurikuum, dan evaluasi. Masing-masing komponen ini akan dijelaskan secara singkat sebagai berikut:

\section{Pendidik Profesional}

Peranan dosen profesional sangat menentukan dalam inovasi model pembelajaran karena berhubungan dengan peningkatan kualitas pendidikan. Profesionalisme dosen meliputi penguasaan ilmu pengetahuan atau kemampuan manajemen beserta strategi penerapannya. Dosen profesional dituntut untuk mempunyai komitmen kepada mahasiswa dalam pembelajaran, menguasai materi kuliah yang diajarkan serta mengetahui cara pembelajarannya, bertanggungjawab memantau hasil belajar mahasiswa melalui berbagai jenis evaluasi, mampu berpikir sistematis tentang apa yang dilakukannya dan belajar dari pengalamannya. Dosen profesional akan selalu berusaha untuk melakukan inovasi model pembelajaran untuk memudahkan penyampaian materi kuliah kepada mahasiswa.

Dalam proses pembelajaran, hasil belajar mahasiswa sangat dipengaruhi oleh faktor berikut: (1) gaya pribadi dosen dan bentuk pengajaran yang digunakan, termasuk diantarannya adalah nada suara, perhatian dan penekanan; (2) materi pelajaran yang disajikan, dan (3) keterampilan atau teknik penyampaian materi kuliah yang digunakan. Faktor (1) dan (2) mungkin sulit untuk diubah, akan tetapi faktor (3) dapat dengan mudah diperbaiki melalui pembelajaran dan pengalaman. Agar pengajaran berhasil dengan baik maka beberapa hal yang perlu diperhatikan, yaitu persiapan, pelaksanaan dan umpan balik. Persiapan pengajaran yang baik akan dapat digunakan sebagai jaminan hasil dalam pelaksanaan pembelajaran. Persiapan bukan hanya mempelajari apa yang akan diajarkan, karena setiap dosen dianggap telah menguasai bahan yang akan diajarkan. Yang utama dalam persiapan pengajaran adalah strategi penyusunan materi kuliah dan pengaturan penyampaian materi agar lebih sistematis dan mudah dimengerti. Dalam hal ini perlu inovasi model pembelajaran yang sesuai untuk penyampaian materi kuliah. Keterbatasan pengetahuan inovator akan menjadi penghalang dalam inovasi model pembelajaran.

\section{Mahasiswa}

Agar mutu pembelajaran dapat ditingkatkan, maka tidak terlepas dari mahasiswa yang ikut serta dalam proses pembelajaran. Mahasiswa harus ditempatkan sebagai pusat kegiatan pembelajaran sehingga inovasi model pembelajaran harus selalu mempertimbangkan kebutuhan mahasiswa. harus selalu dipikirkan bahwa kelompok mahasiswa yang berbeda mempunyai kemampuan berbeda, sehingga memotivasi mahasiswa dalam kegiatan pembelajaran sangat diperlukan karena rendahnya daya juang mahasiswa seperti sekarang ini akan mengakibatkan keengganan belajar, yang pada akhirnya akan mempengaruhi terhadap kualitas lulusan. Untuk memotivasi mahasiswa dalam belajar diperlukan inovasi model pembelajaran agar proses pembelajaran dapat memberikan suasana kondusif terhadap mahasiswa dan dapat menuntun mereka belajar aktif, bebas menggali dan mem- 
bentuk kompetensi ilmu, keterampilan, sikap perilaku dan kepribadian profesi.

\section{Sarana Dan Prasarana}

Sarana dan prasarana pendidikan sangat menentukan dalam penerapan inovasi model pembelajaran. Inovasi model pembelajaran akan sulit berkembang bila tidak didukung oleh sarana dan prasarana pendidikan. Penyediaan dan penggunaan sarana dan prasarana pendidikan secara optimum akan dapat meningkatkan kualitas pembelajaran. Gedung dan ruang kuliah serta perlengkapannya perlu mendapat perhatian dari segi kelayakannya untuk mendukung penerapan model pembelajaran yang dipersiapkan. Loboratorium sebagai ajang latih dan praktek mahasiswa perlu dilengkapi dengan fasilitas yang sesuai untuk inovasi pembelajaran. Lemahnya faktor penunjang sarana dan prasarana akan menjadi kendala dalam inovasi model pembelajaran. Keterbatasan keuangan yang tidak terpenuhi dalam mendukung pelaksanaan inovasi model pembelajaran juga harus disiasati dalam mensukseskan inovasi model pembelajaran.

\section{Pembelajaran}

Pembelajaran sangat berpengaruh terhadap keberhasilan inovasi model pembelajaran dan juga inovasi model pembelajaran dapat meningkatkan proses pembelajaran. Tujuan pembelajaran bukanlah semata-mata transfer pengetahuan dan keterampilan, yaitu menjadikan mahasiswa dari tidak tahu menjadi tahu, akan tetapi harus mampu membina mahasiswa menjadi kreatif, mahir dan terampil. Proses pembelajaran hendaknya mampu menumbuhkan, menyempurnakan dan meningkatkan pola laku tertentu dalam diri mahasiswa, yaitu kerangka dasar dari kegiatan yang dilakukan oleh manusia dalam usaha mempertahankan hidup di masyarakat agar mahasiswa dapat bertindak secara rasional dan mampu menimbulkan kebiasaan baik bagi diri sendiri.

Pendidik harus menyadari pesatnya perkembangan teknologi dan informasi saat ini yang mengarah pada terjadinya peradaban manusia menjadi global. Informasi terkini secara bebas telah dapat diakses oleh mahasiswa. informasi tersebut mungkin masih tabu bagi sebagian orang, atau mungkin bagi orang lain sulit untuk dijelaskan, sehingga banyak perubahan-perubahan yang telah terjadi menjadi membingungkan. Oleh sebab itu, agar komunikasi antara dosen dan mahasiswa berjalan dengan baik maka inovasi model pembelajaran juga harus disesuaikan dengan perubahan yang terjadi. Dosen harus memberikan kesempatan dan ruang gerak kepada mahasiswa untuk menjelaskan apa yang sudah mereka ketahui dan menanyakan apa yang mereka inginkan. Dengan demikian, inovasi model pembelajaran harus dapat menggairahkan proses pembelajaran agar mahasiswa dibina dan diarahkan untuk memiliki pola pikir, keterampilan dan kebiasaan terbuka, tanggap dan mampu menyesuaikan diri dengan lingkungannya.

\section{Kurikulum}

Inovasi model pembelajaran tidak dapat dipisahkan dari kurikulum pendidikan. Untuk menghasilkan model pembelajaran yang berkualitas maka kurikulum yang digunakan juga harus mengikuti program-program yang ada di dalamnya. Dalam penerapan model pembelajaran hendaknya disesuaikan dengan perubahan-perubahan atau perubahan kurikulum diikuti dengan pembaharuan model pembelajaran atau perubahan secara bersama-sama. Menyelaraskan model pembelajaran dengan kurikulum dapat dilakukan dengan melibatkan mahasiswa dan dosen untuk memberikan masukan yang berguna kepada innovator 
dalam melakukan inovasi model pembelajaran yang lebih baik.

\section{Evaluasi}

Agar model pembelajaran dapat berjalan dengan baik maka semua pihak harus dilibatkan dalam inovasi sebelum penerapannya di lapangan. Evaluasi dan monitoring harus dilakukan untuk mengetahui tingkat penolakan dari sekelompok tertentu atas hasil inovasi. Evaluasi sangat penting untuk mengetahui tingkat keberhasilan model pembelajaran, yaitu melihat pengaruh model pembelajaran dalam meningkatkan prestasi belajar mahasiswa. melalui hasil evaluasi akan diketahui kekuatan dan kelemahan model pembelajaran terutama bila memerlukan penyempurnaan pada penggunaan berikutnya.

\section{DAFTAR RUJUKAN}

Boyce, LN., Van TasselBaska, J., Burruss, J.D., Sher, B.T., dan Johnson, D.T., (1997), A ProblemBased Curriculum: Parallel Learning Opportunities for Students and Teachers, Journal of Education of the Gifed 20:363-379

Cann, M.C., dan Dickneider, T.A. 2004. Infusing The Chemistry Curriculum With Green Chemistry Using Real-World Examples, Web Modules, And Atom Economy In Organic Chemistry Course, Journal of Chemical Education 81:977980)

Forsyth, I., Jolliffe, A., dan Stevens, D. 2004. Practical Strategies for Teachers, Lecturers and Trainers, Delivering Vol 3, Crest Publishing House, New Delhi.

Giancarlo, L.C. dan Slunt, K.M . 2004. Thedog ate my homework: A Cooperative Learning Project for

\section{KESIMPULAN}

Inovasi pembelajaran sangat diperlukan dalam peningkatan penguasaan mahasiswa terhadap materi perkuliahan. Keberhasilan inovasi model pembelajaran dalam meningkatkan prestasi mahasisw sangat ditentukan oleh kesesuaian model pengajaran dengan materi kuliah dan tujuan pembelajaran. Beberapa komponen yang perlu dipertimbangkan dalam inovasi model pembelajaran adalah dosen, mahasiswa, sarana dan prasarana pendidikan, proses pembelajaran, kurikulum, monitoring dan evaluasi. Hasil penelitian menunjukkan bahwa model pembelajaran menggunakan media petakonsep, model pembelajaran menggunakan komputer, dan model pembelajaran berbasis web yang dimodifikasi sangat efektif dalam meningkatkan prestasi belajar mahasiswa.

Instrument Analysis, Journal of Chemical Education 81:868-869.

Glynn, S.M., Law, M., Gibson, N.M., dan Hawkins, C.H. 2001. Teaching Science With Analogies, A Resource for Teachers And Text Book Authors, University of Georgia.

Joice, B. dan Weil, M. 1980. Models of Teaching, $2^{\text {nd }}$ ed. Prentice-Hall International Inc. Englewood Cliffs, New Jersey.

Rosenberg, M.J. 2001. E-Learning Strategies for Delivering Knowledge in the Digitalage, McGrawHill, New York

Shakkashiri, B.Z. 1991. Chemical demonstration. A hand book for teacher of chemistry, The University of Winconsein Press.

Situmorang, M. 2003. Efektivitas Mo-del Pembelajaran terhadap Pe- 
ningkatan Prestasi Belajar Mahasiswa dalam Perkuliahan Kimia Analitik-I), Laporan Hasil Penelitian, FMIPA Universitas Negeri Medan.

Situmorang, M., Purba, J., dan Tambunan, M. 2000. Efektifitas Me-dia Petakonsep dalam Pengajaran
Kimia Konsep Mol di SMU, Pelangi pendidikan 7(1): 31-35

Slocum, L.E., Towns, M.H., dan Zielinski, T.J. 2004. Online Chemistry Module: Interaction and Effective Faculty Facilition, Journal of Chemical Education 81:1058-1065 